\title{
Comparison of the volatiles composition between healthy and buprestid infected Juglans regia (Juglandaceae)
}

\author{
Comparación de la composición de los volátiles de Juglans regia (Juglandaceae) sanos \\ e infestadas por un escarabajo bupréstido
}

\author{
YAQIN CUI ${ }^{1}$; SHUQING KONG ${ }^{2}$; XINHAI LIU ${ }^{3}$; SUICUN LIU ${ }^{4}$
}

\begin{abstract}
${ }^{1}$ Post-Doc. Shanxi Academy of Forestry Sciences, Taiyuan, Shanxi, 030012, China, sxtycyq@foxmail.com, https://orcid.org/0000-0001-9764-8425. ${ }^{2}$ Department head. The Bureau Forestry of Linfen City, Linfen, Shanxi, 041000, China, lflyjstgz@163.com, https://orcid.org/0000-0002-8786-0892. ${ }^{3}$ Master. Ulanqab Gardens Bureau, Ji'ning District of Ulanqab, Ulanqab, Inner Mongolia Autonomous Region, 012000, China, 175601540@qq.com, https://orcid.org/0000-0003-42433798. ${ }^{4}$ Prof. Shanxi Academy of Forestry Sciences, Taiyuan, Shanxi, 030012, China, 13934131208@126.com, https://orcid.org/0000-0001-7090-9621.
\end{abstract}

Corresponding author: Suicun Liu, Prof. Shanxi Academy of Forestry Sciences, Taiyuan, Shanxi, 030012, China, 13934131208@126. com, https://orcid.org/0000-0001-7090-9621.

Suggested citation:

CUI, Y.; KONG, S.; LIU, X.; LIU, S. 2020 Comparison of the volatiles composition between healthy and buprestid infected Juglans regia (Juglandaceae). Revista Colombiana de Entomología 46 (1): e8649. https://doi. org/10.25100/socolen.v46i1.8649

Received: 28-Feb-2018

Accepted: 06-Aug-2019

Published: 9-Jul-2020

Revista Colombiana de Entomología

ISSN (Print): 0120-0488

ISSN (On line): 2665-4385

http://revistacolombianaentomologia.univalle.edu.co/

Open access

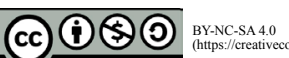

Publishers:

Sociedad Colombiana de Entomología

SOCOLEN (Bogotá, D. C., Colombia)

http://www.socolen.org.co

Universidad del Valle (Cali, Colombia)

http://www.univalle.edu.co/

(C) 2020 Sociedad Colombiana de Entomología - SOCOLEN y Universidad del Valle - Univalle
Abstract: Meliboeus ohbayashii primoriensis (Coleoptera: Buprestidae) is an important pest of the walnut tree Juglans regia (Juglandaceae), but the volatiles mediating this plantherbivore interaction are unknown. In this study, volatiles emitted by healthy J. regia and by plants infested with $M$. ohbayashii primoriensis (Coleoptera: Buprestidae) were obtained by a dynamic headspace method and analyzed by gas chromatography-mass spectrometry. We identified 26 major compounds and compared the volatile composition of healthy and buprestid-infected $J$. regia. Green leaf volatiles were detected in all damaged plants, including the monoterpenoids $\beta$-phellandrene and $(E)$ - $\beta$-ocimene, the sesquiterpenoids (-)- $\beta$-bourbonene, $\beta$-ylangene, and $(E, E)$ - $\alpha$-farnesene, the alcohols linalool, myrtenol, and $(E)$ $(-)$-pinocarveol, the ketones $(E)$-pinocamphone and $(Z)$-pinocamphone, and the ester methyl salicylate. The major volatiles detected in healthy plants were $\beta$-pinene $(36.26 \%), \alpha$-pinene $(23.81 \%)$, D-limonene $(12.03 \%)$, sabinene $(8.63 \%)$, and $\beta$-myrcene $(4.35 \%)$. The main volatiles from $M$. ohbayashii primoriensis larva-infested plants were $\beta$-pinene $(37.82 \%)$, $\alpha$-pinene $(20.36 \%)$, D-limonene (14.71\%), germacrene D $(5.24 \%)$, sabinene $(4.52 \%)$, and $\beta$-phellandrene $(3.80 \%)$. These results enrich our understanding of volatiles of healthy plants and plants infested with M. ohbayashii primoriensis. Furthermore, they provide a theoretical basis and scientific foundation for integrated pest management and for effective ecologically sustainable pest control strategies.

Keywords: Juglans, Meliboeus ohbayashii primoriensis, volatile compounds, plant-herbivore interaction, Coleoptera, Buprestidae.

Resumen: Meliboeus ohbayashii primoriensis (Coleoptera: Buprestidae) es una plaga importante del nogal Juglans regia (Juglandaceae), pero se desconocen los compuestos volátiles que median esta interacción planta-herbívoro. En este estudio, se obtuvieron los volátiles emitidos por plantas de $J$. regia tanto sanas como infestadas con $M$. ohbayashii primoriensis (Coleoptera: Buprestidae), mediante un método de espacio de cabeza dinámico y se analizaron por cromatografía de gases-espectrometría de masas. Se identificaron 26 compuestos principales y se comparó la composición volátil de $J$. regia sana e infectada con bupréstido. Se detectaron volátiles de hojas verdes en todas las plantas dañadas, incluidos los monoterpenoides $\beta$-felandreno y $(E)$ - $\beta$-ocimeno, los sesquiterpenoides (-)- $\beta$-bourboneno, $\beta$-ylangeno y $(E, E)$ - $\alpha$-farnesano, los alcoholes linalool, mirtenol y $(E)-(-)$-pinocarveol, las cetonas $(E)$-pinocamfono y $(Z)$-pinocamfono, y el éster salicilato de metilo. Los principales volátiles detectados en plantas sanas fueron $\beta$-pineno $(36,26 \%), \alpha$-pineno $(23,81 \%)$, D-limoneno $(12,03 \%)$, sabineno $(8,63 \%)$ y $\beta$-mirceno $(4,35 \%)$. Los principales volátiles de las plantas infestadas de larvas de $M$. ohbayashii primoriensis fueron $\beta$-pineno $(37,82$ $\%)$, $\alpha$-pineno $(20,36 \%)$, D-limoneno $(14,71 \%)$, germacreno D $(5,24 \%)$, sabineno $(4,52 \%)$, y $\beta$-felandreno $(3,80 \%)$. Estos resultados enriquecen nuestra comprensión de los volátiles de plantas sanas e infestadas con M. ohbayashii primoriensis. Además, proporcionan una base teórica y una científica para el manejo integrado de plagas y para estrategias efectivas, ecológicamente sostenibles, para el control de plagas.

Palabras clave: Juglans, Meliboeus ohbayashii primoriensis, compuestos volátiles, interacción planta-herbívoro, Coleoptera, Buprestidae.

\section{Introduction}

The walnut Juglans regia L. (1753) (Juglandales: Juglandaceae) is an economically important cultivated trees species. J. regia is widely distributed in China (north to Heilongjiang Province, south to Yunnan Province and Guizhou Province, west to Xinjiang Uygur Autonomous Region, and east to Shandong Province, Liaoning 
Province). It has nutritional and medicinal value (Ma et al. 2006; Xu et al. 2006; Wang et al. 2006; Zhou and Lv 2006); therefore, the walnut is classified as a strategic species for human nutrition and is included in the FAO priority list of plants (Gandev 2007).

The main herbivore affecting $J$. regia is Meliboeus ohbayashii primoriensis (Alexeev, 1979) (Coleoptera: Buprestidae) (Wang et al. 2018). M. ohbayashii primoriensis is univoltine and overwinter as larvae on branches, with pupation beginning in mid to late April and adult emergence in early May to early July. Female adults lay eggs on leaf scars of $J$. regia. The larvae are distributed on the branches of 2- to 3 -year-old plants and mainly cause damage to branch bark. Adult $J$. regia feed on leaves. Although the species does not kill host plants immediately, it can reduce water and nutrient flow, resulting in leaf loss and reduced fruit yields and thereby contributing to tree mortality (Wang and Li 1993; Chen et al. 2015; Wang et al. 2015).

Plant volatiles, used for chemical signaling, affect insect behavior and can contribute to interactions between plants and insects. Specific plant volatiles can help insects locate a plant and select an oviposition site or can serve as repellents (Heil and Ton 2008; Hiltpold et al. 2010; Gish et al. 2015). Many recent studies have focused on the behavioral responses of insects to host volatile emissions; both the quantitative and qualitative characteristics of herbivore-induced changes in the emission of volatiles have attracted increasing attention (Nottingham et al. 1991; Musetti and Neal 1997; Kessler and Baldwin 2001; Mauck et al. 2010; Ramadan et al. 2011; Tamiru et al. 2012). The emerald ash borer locates its host, Agrilus planipennis (Fairmaire, 1888) (Coleoptera: Buprestidae), by plant volatile emissions (Rodriguez-Saona et al. 2006; Grant et al. 2010). It is specifically attracted by (3Z)lactone and (3Z)-hexenol from leaves of host plants (Groot et al. 2008; Ryall et al. 2012; Ryall et al. 2013). Prior work has evaluated volatiles from healthy walnut leaves, husks, and kernel oils (Farag 2008; Abdallah et al. 2015; Sarles et al. 2017) as well as the behavioral response of pests to volatiles of healthy plants, such as Rhagoletis completa (Cresson, 1929) (Diptera: Tephritidae), Cydia pomonella (L., 1758), (Lepidoptera: Tortricidae), Amyelois transitella (Walker, 1863) (Lepidoptera: Pyralidae), and Batocera horsfieldi Hope, 1839 (Coleoptera: Cerambycidae) (Yang et al. 2011; Román et al. 2015; Sarles et al. 2017). However, studies of the volatiles of $J$. regia infested with $M$. ohbayashii primoriensis are lacking. We compared the emission of volatiles from $J$. regia infested with $M$. ohbayashii primoriensis and healthy control plants. The objective of this study was to improve our understanding of host plant volatiles and to provide a basis for the development of ecologically sustainable strategies for herbivore control.

\section{Materials and methods}

Plant material. An infested J. regia fruit garden of $26.67 \mathrm{hm}^{2}$, located in Yonghe County, Shanxi, China, was studied. Ten individuals of $J$. regia were chosen for headspace collection. All plants were 20 years old with an average diameter at breast height of $19.9 \mathrm{~cm}$, tree height of 6-8 $\mathrm{m}$, and crown diameter of 5-6 m.

Herbivore material. $J$. regia was widely infested with $M$. ohbayashii primoriensis. Larvae were observed at densities of 10-15 larvae/tree. Volatile compounds were collected from walnuts infested with M. ohbayashii primoriensis.

Headspace collection. At 9:00 am each day, volatiles were collected from healthy and herbivore-infested plants using a dynamic headspace method following a procedure similar to that described by Bäckman et al. (2001). Each aerial part was covered with an oven bag $(48.26 \mathrm{~cm} \times 23 \mathrm{~cm} \times 1.27$ cm; Reynolds, Richmond, CA, USA). The air was first exhausted from the bag, and the bag was then refilled with air percolated through an activated charcoal filter. Plastic bags were used only once to avoid contamination. For sampling, air was cycled through the oven bag, which was connected to a glass tube (length, $10.60 \mathrm{~cm}$; inner diameter, $0.35 \mathrm{~cm}$; outer diameter $0.85 \mathrm{~cm}$ ) and filled with $200 \mathrm{mg}$ of Porapak Q (80/100 mesh; Waters Corporation, Milford, MA, USA). Plant volatiles were sampled for 3 hours using a portable batteryoperated air sampler with a constant flow of $100 \mathrm{ml} / \mathrm{min}$. Subsequently, the glass tubes were taken to the laboratory and washed five times with $200 \mu \mathrm{l}$ of dichloromethane to extract samples into $2 \mathrm{ml}$ clear screw vials with patch Borosilicate $(9$ $\mathrm{mm}, \mathrm{CNW}$ ). The vials were kept at $-20^{\circ} \mathrm{C}$ until analysis.

GC-MS analysis. A Shimadzu 2010 (Shimadzu, Tokyo, Japan) gas chromatograph was equipped with a split-splitless auto-injector (model AOCi) and an auto sampler (model AOC-20i), and a MS-QP 2010 (Shimadzu) series mass selective detector was used for sample analysis. The analytical conditions were as follows: GC: column, Rtx-5MS $(30.0 \mathrm{~m} \times$ $0.25 \mathrm{~mm} \times 0.25 \mu \mathrm{m}$; J\&W, Palo Alto, CA, USA); carrier gas, helium; flow rate, $1.01 \mathrm{ml} / \mathrm{min}$; column temperature, $40^{\circ} \mathrm{C}$ held for $2 \mathrm{~min}$, then at the rate of $6^{\circ} \mathrm{C} / \mathrm{min}$ to $180^{\circ} \mathrm{C}$ (held for $2 \mathrm{~min}$ ), and $15{ }^{\circ} \mathrm{C} / \mathrm{min}$ to $270{ }^{\circ} \mathrm{C}$. MS: analytical mode, full-scan; mass range, m/z 50-400.

Identification of volatile compounds. Retention indices (RI) were calculated based on retention times of n-alkanes, which were injected after volatiles under the same conditions. Relative contents were calculated based on GC peak areas without correction factors. The volatile compounds were identified by comparing mass spectral data with those of authentic samples in a mass spectra library (Turbo Mass ver. 5.4.2, NIST11), and the compounds were confirmed by comparing RI values with published data (Davies 1990; Farag 2008; Abdallah et al. 2016).

Statistical analysis. All measurements were obtained in six replicates and statistical analyses were performed using Microsoft Excel 2007. Results are presented as averages \pm SEM.

\section{Results}

Volatile compound detection. The volatile compounds identified from healthy plants and plants infested by $J$. regia are listed in Table 1. We identified 26 major volatile compounds. With respect to green leaf volatiles, we detected the monoterpenoids $\beta$-phellandrene and $(E)-\beta$-ocimene, the sesquiterpenoids (-)- $\beta$-bourbonene, $\beta$-ylangene, $(E, E)$ $\alpha$-farnesene, the alcohols linalool, myrtenol, and $(E)-(-)$ -pinocarveol, the ketones (E)-pinocamphone and $(Z)$ pinocamphone, and the ester methyl salicylate in all herbivoreinfested plants. 
Healthy J. regia. The volatile constituents of the aerial parts of $J$. regia were mainly classified as terpenoids $(93.54$ $\%)$ (monoterpenoids $(86.03 \%)$ and sesquiterpenoids $(7.51$ $\%)$ ), esters (2.62\%), alcohols (1.43\%), ketones (1.08\%), and aromatic hydrocarbons $(0.23 \%)$. The most abundant components were $\beta$-pinene (36.26\%), $\alpha$-pinene $(23.81 \%)$, D-limonene $(12.03 \%)$, sabinene $(8.63 \%)$, and $\beta$-myrcene $(4.35 \%)$.

Buprestid beetle-infested (herbivore-infested plants) J. regia. Buprestid beetle-infested volatiles were mainly classified as terpenoids (95.37\%) [monoterpenoids (84.67\%) and sesquiterpenoids $(10.70 \%)$, alcohols $(2.11 \%)$, ketones

Table 1. Compositional variation in healthy $(\mathrm{H})$ and buprestid beetleinfestation (AR) Juglans regia.

\begin{tabular}{|c|c|c|c|c|c|}
\hline \multirow{2}{*}{ No. } & \multirow{2}{*}{ Compounds } & \multirow{2}{*}{$\begin{array}{c}\mathrm{RI}^{\mathrm{a}} \\
\text { sample }\end{array}$} & \multirow{2}{*}{$\begin{array}{c}\text { RI } \\
\text { stand. }\end{array}$} & \multicolumn{2}{|c|}{ Relative content \pm SE (\%) } \\
\hline & & & & $\mathbf{H}$ & $\mathbf{A R}$ \\
\hline \multicolumn{6}{|c|}{ Monoterpene hydrocarbons } \\
\hline 1 & $\alpha$-Pinene & 939 & 940 & $23.81 \pm 0.20$ & $20.36 \pm 0.22$ \\
\hline 2 & Camphene & 947 & 950 & $0.95 \pm 0.05$ & $0.31 \pm 0.04$ \\
\hline 3 & Sabinene & 973 & 973 & $8.63 \pm 0.22$ & $4.52 \pm 0.18$ \\
\hline 4 & $\beta$-Pinene & 976 & 978 & $36.26 \pm 0.25$ & $37.82 \pm 0.20$ \\
\hline 5 & $\beta$ - Myrcene & 991 & 989 & $4.35 \pm 0.21$ & $2.90 \pm 0.20$ \\
\hline 6 & D-Limonene & 1027 & 1029 & $12.03 \pm 0.08$ & $14.71 \pm 0.21$ \\
\hline 7 & $\beta$-Phellandrene & 1031 & 1031 & $-b$ & $3.80 \pm 0.19$ \\
\hline 8 & $(E)$ - $\beta$-Ocimene & 1050 & 1052 & $-b$ & $0.25 \pm 0.09$ \\
\hline \multicolumn{6}{|c|}{ Sesquiterpene hydrocarbons } \\
\hline 9 & $(-)-\beta$-Bourbonene & 1384 & 1384 & $-b$ & $0.40 \pm 0.03$ \\
\hline 10 & Longifolene & 1398 & 1399 & $1.22 \pm 0.04$ & $0.77 \pm 0.05$ \\
\hline 11 & $\beta$-ylangene & 1428 & 1428 & $-b$ & $0.42 \pm 0.01$ \\
\hline 12 & 1-Caryophyllene & 1434 & 1435 & $1.52 \pm 0.02$ & $-b$ \\
\hline 13 & (E)- $\beta$-Farnesene & 1440 & 1440 & $2.13 \pm 0.02$ & $3.50 \pm 0.05$ \\
\hline 14 & $(E, E)$ - $\alpha$-Farnesene & 1458 & 1458 & $-b$ & $0.37 \pm 0.03$ \\
\hline 15 & Humulene & 1454 & 1454 & $0.38 \pm 0.01$ & $-b$ \\
\hline 16 & Germacrene D & 1490 & 1491 & $2.26 \pm 0.02$ & $5.24 \pm 0.04$ \\
\hline \multicolumn{6}{|c|}{ Esters } \\
\hline 17 & (Z)-3-Hexen-1-ol acetate & 992 & 993 & $2.62 \pm 0.05$ & $0.58 \pm 0.02$ \\
\hline 18 & Methyl salicylate & 1190 & 1190 & $-b$ & $0.12 \pm 0.01$ \\
\hline \multicolumn{6}{|c|}{ Alcohols } \\
\hline 19 & Eucalyptol & 1059 & 1060 & $1.43 \pm 0.04$ & $1.75 \pm 0.02$ \\
\hline 20 & Linalool & 1082 & 1084 & $-b$ & $0.27 \pm 0.02$ \\
\hline 21 & (E)-(-)-Pinocarveol & 1131 & 1132 & $-b$ & $0.04 \pm 0.06$ \\
\hline 22 & Myrtenol & 1191 & 1189 & $-b$ & $0.05 \pm 0.03$ \\
\hline \multicolumn{6}{|c|}{ Ketones } \\
\hline 23 & (E)-Pinocamphone & 1164 & 1164 & $-b$ & $0.12 \pm 0.08$ \\
\hline 24 & (Z)-Pinocamphone & $1165^{\mathrm{c}}$ & $1165 \mathrm{c}$ & $-b$ & $0.81 \pm 0.06$ \\
\hline 25 & m-Ethylacetophenone & $1242^{\mathrm{c}}$ & $1244 \mathrm{c}$ & $1.08 \pm 0.09$ & $0.04 \pm 0.08$ \\
\hline \multicolumn{6}{|c|}{ Aromatic hydrocarbons } \\
\hline 26 & Indane & $1047^{c}$ & $1048^{\mathrm{c}}$ & $0.23 \pm 0.02$ & $0.03 \pm 0.01$ \\
\hline
\end{tabular}

${ }^{\mathrm{a}}$ Observed retention index. ${ }^{\mathrm{b}}$ Not detected. ${ }^{\mathrm{c}}$ Compounds for which RI values have not been previously reported in the literature. Compounds were verified by comparison with an authentic standard when possible and compared to internally generated database values. When standards were not available, retention indexes and/or mass spectra were only compared with internally generated data and/or with NIST (NIST02).
$(0.97 \%)$, esters $(0.70 \%)$ and aromatic hydrocarbons $(0.03$ $\%)$. The most abundant components were $\beta$-pinene (37.82 $\%)$, $\alpha$-pinene $(20.36 \%)$, D-limonene $(14.71 \%)$, germacrene $\mathrm{D}(5.24 \%)$, sabinene $(4.52 \%)$, and $\beta$-phellandrene (3.80\%). Additionally, we detected the monoterpenoids $\beta$-phellandrene and trans- $\beta$-ocimene, sesquiterpenoids $\beta$-ylangene, $(-)-\beta$-bourbonene, and $(E, E)-\alpha$-farnesene, alcohols linalool, myrtenol, and $(E)-(-)$-pinocarveol, ketones $(Z)$-pinocamphone and $(E)$-pinocamphone, and ester methyl salicylate in herbivore-infested plants.

In addition to these qualitative differences, beetle infestation induced quantitative changes in the proportions of terpenoids. In particular, $\beta$-pinene, D-limonene, germacrene $\mathrm{D}$, and $(E)-\beta$-farnesene contents were higher and $\alpha$-pinene, sabinene, $\beta$-myrcene, camphene, and longifolene contents were lower in infested plants than in healthy plants.

\section{Discussion}

Herbivore attacks increase the emission of volatiles (Kessler and Baldwin 2001). The release of volatiles can improve plant resistance by attracting natural enemies (parasitoids and predators) of the herbivore as an indirect defense mechanism (Metcalf and Kogan 1987; Dicke 1994; Turlings and Benrey 1998; Kessler and Baldwin 2001).

Terpenoids are the largest class of natural products. Terpenoid phytoalexins play important roles in attacking herbivores by direct and indirect defense mechanisms (Mumm and Hilker 2006; Gershenzon and Dudareva 2007). The volatiles D-limonene, sabinene, $\alpha$-pinene, $(E, E)$ - $\alpha$ farnesene, $(E)$ - $\beta$-ocimene, and methyl salicylate, which we detected in our experiments, are very important compounds for the attraction of herbivore enemies (Hardie et al. 1994; Ament et al. 2010).

The relative $\beta$-pinene content was higher after herbivore attack than in healthy plants. Inversely, $\alpha$-pinene contents were lower in infested plants than in healthy plants. The ratio of $\alpha$-pinene to $\beta$-pinene was higher in healthy $J$. regia than in plants infested with $M$. ohbayashii primoriensis. Ning et al. (2006) concluded that a low ratio of $\alpha$-pinene to $\beta$-pinene indicates declining host health, consistent with our observations of a relatively low ratio in infested plants. However, further research is needed to verify whether the condition of host plants could be determined by the ratio of $\alpha$-pinene to $\beta$-pinene.

We detected eucalyptol in healthy plants. Eucalyptol, linalool, myrtenol, and (E)-(-)-pinocarveol were present in all herbivore-infested plants. Alcohol compounds play an important role in the attraction of herbivores (Kessler and Baldwin 2001). We detected (Z)-3-hexen-1-ol acetate and methyl salicylate in herbivore-infested plants, both of which contribute to the attraction of herbivore enemies (Hardie et al. 1994; James 2003).

We analyzed the volatiles emitted by healthy $J$. regia and plants infested with M. ohbayashii primoriensis. We detected qualitative and quantitative differences in the volatile profiles, with particularly notable variation in the terpenoids composition. Dynamic headspace coupled with GC/MS was suitable for the qualitative and quantitative investigation of volatiles in walnut. This approach can be used for further investigations of plant-derived attractants of herbivore enemies, volatile compositions, and ecologically sustainable strategies for the control of pests. 


\section{Conclusion}

Our results expand our understanding of volatiles for the location, manipulation, or alteration of the chemical ecology of the environment to protect or improve walnut, a valuable natural resource.

\section{Acknowledgements}

We gratefully acknowledge Professor Luo Youqing and Zongshi Xiang, Dr. Ren Lili, Liu Xiaobo and Gao Chenglong from Beijing Forestry University for providing experiment instruments for this study. Furthermore, we gratefully acknowledge Director Ren Dongming and Lin Hejie from Yonghe county forestry bureau in Shanxi Province for helping us to collect data in field.

\section{Literature cited}

AMENT, K.; KRASIKOV, V.; ALLMANN, S.; REP, M.; TAKKEN, F. L.W.; SCHUURINK, R. C. 2010. Methyl salicylate production in tomato affects biotic interactions. Plant Journal 62 (1): 124134. https://doi.org/10.1111/j.1365-313X.2010.04132.x

ABDALLAH, I. B.; TLILI, N.; MARTINEZ-FORCE, E.; RUBIO, A. G. P.; PEREZ-CAMINO, M. C.; ALBOUCHI, A. L. I., BOUKHCHINA, S. 2015. Content of carotenoids, tocopherols, sterols, triterpenic and aliphatic alcohols, and volatile compounds in six walnuts (Juglans regia L.) varieties. Food Chemistry 173: 972-978. https://doi.org/10.1016/j.foodchem.2014.10.095

ABDALLAH, I. B.; BAATOUR, O.; MECHRGUI, K.; HERCHI, W.; ALBOUCHI, A.; CHALGHOUM, A.; BOUKHCHINA, S. 2016. Essential oil composition of walnut tree (Juglans regia L.)' leaves from Tunisia. Journal of Essential Oil Research 28 (6): 545-550. https://doi.org/10.1080/10412905 .2016.1166157

BÄCKMAN, A. C.; BENGTSSON, M.; BORG-KARLSSON, A. K.; LIBLIKAS, I.; WITZGALL, P. 2001. Volatiles from apple (Malus domestica) eliciting antennal responses in female codling moth Cydia pomonella (L.) (Lepidoptera: Tortricidae): effect of plant injury and sampling technique. Zeitschrift für Naturforschung C 56 (3-4): 262-268. https://doi.org/10.1515/ znc-2001-3-415

CHEN, C.; LI, X. Q.; YANG, M. X.; GUO, X. X. 2015. Investigation of pests and control technologies of major pests of Juglans regia in Shaanxi. Journal of Agriculture 5 (9): 64-68. http://en.cnki. com.cn/Article en/CJFDTotal-XKKJ201509014.htm

DAVIES, N. W. 1990. Gas chromatographic retention indices of monoterpenes and sesquiterpenes on methyl silicon and Carbowax 20M phases. Journal of Chromatography A 503 (503): 1-24. https://doi.org/10.1016/S0021-9673(01)81487-4

DICKE, M. 1994. Local and systemic production of volatile herbivore-induced terpenoids: their role in plant-carnivore mutualism. Journal of Plant Physiology 143 (4-5): 465-472. https://doi.org/10.1016/S0176-1617(11)81808-0

FARAG, M. A. 2008. Headspace analysis of volatile compounds in leaves from the Juglandaceae (Walnut) family. Journal of Essential Oil Research 20 (4): 323-327. https://doi.org/10.1080/ 10412905.2008.9700023

GANDEV, S. 2007. Budding and grafting of the walnut (Juglans regia L.) and their effectiveness in Bulgaria (Review). Bulgarian Journal of Agricultural Science 13 (6): 683-689. https://www. researchgate.net/publication/268187454

GERSHENZON, J.; DUDAREVA, N. 2007. The function of terpene natural products in the natural world. Nature chemical biology 3 (7): 408-414. https://doi.org/10.1038/nchembio.2007.5

GISH, M.; DE MORAES, C. M.; MESCHER, M. C. 2015. Herbivoreinduced plant volatiles in natural and agricultural ecosystems: open questions and future prospects. Current Opinion in Insect Science 9: 1-6. https://doi.org/10.1016/j.cois.2015.04.001

GRANT, G. G; RYALL, K. L.; LYONS, D. B.; ABOU-ZAID, M. M. 2010. Differential response of male and female emerald ash borers (Col., Buprestidae) to (Z)-3-hexenol and manuka oil. Journal of Applied Entomology 134 (1): 26-33. https://doi. org/10.1111/j.1439-0418.2009.01441.x

GROOT, P. D.; GRANT, G. G.; POLAND, T. M.; SCHARBACH, R.; BUCHAN, L.; NOTT, R. W.; MACDONALD, L.; PITT, D. 2008. Electrophysiological response and attraction of emerald ash borer to green leaf volatiles (GLVs) emitted by host foliage. Journal of Chemical Ecology 34 (9): 1170-1179. https://doi. org/10.1007/s10886-008-9514-3

HARDIE, J.; ISAACS, R.; PICKETT, J. A.; WADHAMS, L. J.; WOODCOCK, C. M. 1994. Methyl salicylate and (-)-(1R, 5S)-myrtenal are plant-derived repellents for black bean aphid, Aphis fabae Scop (Homoptera: Aphididae). Journal of Chemical Ecology 20 (11): 2847-2855. https://doi.org/10.1007/ BF02098393

HEIL, M.; TON, J. 2008. Long-distance signaling in plant defence. Trends in Plant Science 13 (6): 264-272. https://doi. org/10.1016/j.tplants.2008.03.005

HILTPOLD, I.; TOEPFER, S.; KUHLMANN, U.; TURLINGS, T. C. J. 2010. How maize root volatiles affect the efficacy of entomopathogenic nematodes in controlling the western corn rootworm? Chemoecology 20 (2): 155-162. https://doi. org/10.1007/s00049-009-0034-6

JAMES, D. G. 2003. Field evaluation of herbivore-induced plant volatiles as attractants for beneficial insects: Methyl salicylate and the green lacewing, Chrysopa nigricornis. Journal of Chemical Ecology 29 (7): 1601-1609. https://doi. org/10.1023/A:1024270713493

KESSLER, A.; BALDWIN, T. 2001. Defensive function of herbivoreinduced plant volatile emissions in nature. Science 291 (5511): 2141-2144. https://doi.org/10.1126/science.291.5511.2141

MA, L. H.; QIN, W. D.; MIAO, J. Z. 2006. Study on a milk beverage of walnut and hawthorn. Food Research and Development 27 (5): 90-92. http://en.cnki.com.cn/Article_en/CJFDTOTALSPYK200604031.htm

MAUCK, K. E.; DE MORAES, C. M.; MESCHER, M. C. 2010. Deceptive chemical signals induced by a plant virus attract insect vectors to inferior hosts. Proceedings of the National Academy of Sciences of the United States 107 (8): 3600-3605. https://doi. org/10.1073/pnas.0907191107

METCALF, R. L.; KOGAN, M. 1987. Plant volatiles as insect attractants. Critical Reviews in Plant Sciences 5 (3): 251-301. https://doi.org/10.1080/07352688709382242

MUMM, R.; HILKER, M. 2006. Direct and indirect chemical defence of pine against folivorous insects. Trends in Plant Science 11 (7): 351-358. https://doi.org/10.1016/j.tplants.2006.05.007

MUSETTI, L.; NEAL, J. J. 1997. Toxicological effects of Lycopersicon hirsutum f. glabratum and behavioral Response of Macrosiphum euphorbiae. Journal of Chemical Ecology 23 (5): 1321-1332. https://doi.org/10.1023/ B:JOEC.0000006466.63606.0d

NING, T.; FAN, J. T.; FANG, Y. L.; SUN, J. H. 2006. Changes in contents of host Volatile terpenes under different damaged states and electroantennogram response of Monochamus alternatus Hope to these volatiles. Acta Entomologica Sinica 49 (2): 179188. http://en.cnki.com.cn/article_en/cjfdtotal-kcxb200602002. $\mathrm{htm}$

NOTTINGHAM, S. F.; HARDIE, J.; DAWSON, G. W.; HICK, A. J.; PICKETT, J. A.; WADHAMS, L. J.; WOODCOCK, C. M. 1991. Behavioral and electrophysiological responses of aphids to host and nonhost plant volatiles. Journal of Chemical Ecology 17 (6): 1231-1242. https://doi.org/10.1007/BF01402946

RAMADAN, A.; MUROI, A.; ARIMURA, G. 2011. Herbivoreinduced maize volatiles serve as priming cues for resistance against post-attack by the specialist armyworm Mythimna 
separata. Journal of Plant Interactions 6 (2-3): 155-158. https:// doi.org/10.1080/17429145.2010.544775

RODRIGUEZ-SAONA, C.; POLAND, T. M.; MILLER J, R.; STELINSKI, L. L.; GRANT, G. G.; GROOT, P. D.; BUCHAN, L; MACDONAL, L. 2006. Behavioral and electrophysiological responses of the emerald ash borer, Agrilus planipennis, to induced volatiles of Manchurian ash, Fraxinus manchurica. Chemoecology 16 (2): 75-86. https://doi.org/10.1007/s00049005-0329-1

ROMÁN, I. S.; BARTOLOMÉ, L.; GEE, W. S.; ALONSO, R. M.; BECK, J. J. 2015. Comparison of ex situ volatile emissions from intact and mechanically damaged walnuts. Food Research International 72: 198-207. https://doi.org/10.1016/j. foodres.2015.04.009

RYALL, K. L.; SILK, P. J.; MAYO, P.; CROOK, D.; KHRIMIAN, A.; COSSÉ, A. A.; SWEENEY, J.; SCARR, T. 2012. Attraction of Agrilus planipennis (Coleoptera: Buprestidae) to a volatile pheromone: effects of release rate, host volatile, and trap placement. Environmental Entomology 41 (3): 648-656. https:// doi.org/10.1603/EN11312

RYALL, K. L.; FIDGEN, J. G.; SILK, P. J.; SCARR, T. A. 2013. Efficacy of the pheromone (3Z)-lactone and the host kairomone (3Z)-hexenol at detecting early infestation of the emerald ash borer, Agrilus planipennis. Entomology Experimentalis et Applicata 147 (2): 126-131. https://doi.org/10.1111/eea.12052

SARLES, L.; BOULLIS, A.; FASSOTTE, B.; LOGNAY, G.; VERHAEGHE, A.; FRANCIS, F.; VERHEGGEN, F. J. 2017. Identification of walnut husk (Juglans regia L.) volatiles and the behavioural response of the invasive walnut Husk Fly, Rhagoletis completa Cresson. Pest Management Science 73 (10): 2100-2104. https://doi.org/10.1002/ps.4584

TAMIRU, A.; BRUCE, T. J.; MIDEGA, C. A.; WOODCOCK, C. M.; BIRKETT, M. A.; PICKETT, J. A.; KHAN, Z. R. 2012. Oviposition induced volatile emissions from African smallholder farmers' maize varieties. Journal of Chemical Ecology 38 (3): 231-234. https://doi.org/10.1007/s10886-012-0082-1

TURLINGS, T. C. J.; BENREY, B. 1998. Effects of plant metabolites on the behavior and development of parasitic wasps. Ecoscience 5 (3): 321-333. https://doi.org/10.1080/11956860.1998.11682472

WANG, K. J.; HAO, Y. B.; YANG, C. M.; QI, J. X. 2006. The polyphenols in the walnut fruit and the produce to make walnut wine. Academic Periodical of Farm Products Processing 1: 46-47. http://www.wanfangdata.com.cn/details/detail.do? type $=$ perio \&id=ncqjg-xk200601016

WANG, K.; LIU, L. J.; CAI, W. D. 2015. Summary of related research on insect attack of Walnut in China. Journal of Green
Science and Technology (4): 68-73. http://en.cnki.com.cn/ Article_en/CJFDTotal-LVKJ201504031.htm

WANG, R.; LI, Q. S. 1993. Walnut insect pests of Shanxi and their countermeasure control. Journal of Shanxi University (Nat. Sci. Ed.) 16 (1): 107-111. http://en.cnki.com.cn/Article_en/ CJFDTOTAL-SXDR199301022.htm

WANG, X. Y; CAO, L. M; YANG, Z. Q. 2018. Revision of scientific names and re-description of five important buprestid species (Coleoptera: Buprestidae) in China. Acta Entomologica Sinica 61 (10): 1202-1211. http://en.cnki.com.cn/Article_en/ CJFDTotal-KCXB201810010.htm

XU, Z. H.; TAN, J. H.; ZHANG, X.; WANG, L.; LI, W. Y. 2006. Study on the extraction of natural food coloring matter from walnut outer peel and its physical-chemical properties. Journal of Sichuan Normal University 29 (4): 488-490. http://en.cnki. com.cn/Article en/CJFDTOTAL-SCSD200604026.htm

YANG, H.; YANG, W.; YANG, M. F.; YANG, C. P.; ZHU, T. H.; HUANG, Q. 2011. Effects of plant volatiles on the EAG and behavioral responses of Batocera horsfieldi Hope (Coleoptera: Cerambycidae). Journal of Agricultural and Urban Entomology 27 (1): 20-32. https://doi.org/10.3954/10-18.1

ZHOU, Y. Y.; LV, B. 2006. Study on the walnut milk. Food Science and Technology 2: 69-72. http://xueshu.baidu.com/usercenter/ paper $/$ show? paperid $=54 \mathrm{f} 27850153213 \mathrm{be} 14 \mathrm{a} 303 \mathrm{f} 6825 \mathrm{~b} 5950 \& \mathrm{~s}$ ite $=$ xueshu_se

\section{Origin and funding}

This research was supported by Shanxi Province Science Foundation for Youths (Grant No. 201901D211555), and Forestry Science and Technology Innovation Support Program from Shanxi Province Forestry and Grassland Bureau in 2019, the source of funding from Grant No. LYCX201925, and Grant No. LYCX201937.

\section{Author contribution}

Yaqin Cui's main task for this paper is data collection, analysis and article writing work.

Shuqing Kong's main task for this paper is data collection in field.

Xinhai Liu's main task for this paper is the modification and arrangement of this article.

Suicun Liu's main task for this paper is the necessary modifications for the submission and fully responsible for the tasks of this article. 